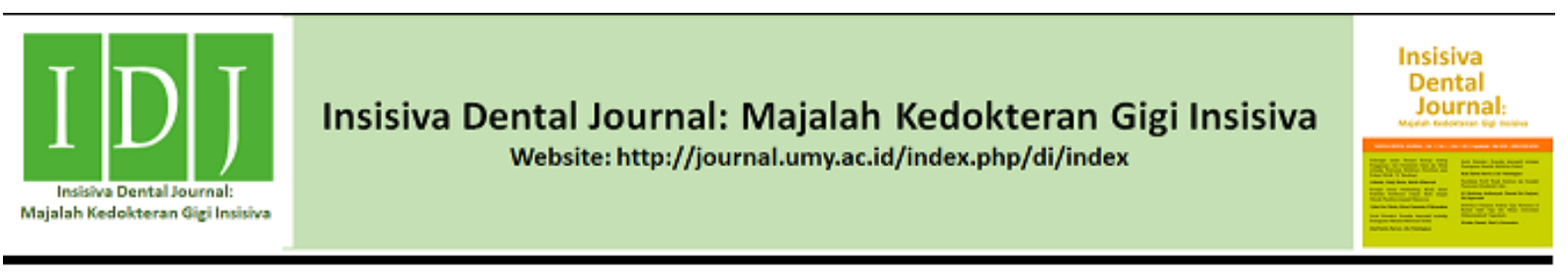

Research Article

\title{
Apigenin Daun Rasamala (Altingia excelsa nornha) Sebagai Antibakteri Enterococcus faecalis
}

Apigenin Leaf of Rasamala (Altingia excelsa nornha) as Antibacterial of Enterococcus faecalis

\author{
Risyandi Anwar* \\ Departemen Kedokteran Gigi Anak, Fakultas Kedokteran Gigi, Universitas Muhammadiyah Semarang, Jalan Kedungmundu No 22 Semarang, \\ Indonesia.
}

Received date: July $24^{\text {th }}, 2018$; reviewed date: August $10^{\text {th }}, 2018$ revised date: October $5^{\text {th }}, 2018$; accepted date: October $31^{\text {st }}, 2018$ DOI : $10.18196 /$ di. 7294

\begin{abstract}
Abstrak
Penyakit pulpa dan periapikal pada anak merupakan salah satu penyakit yang paling sering terjadi pada kasus penyakit gigi dan mulut. Penyakit ini disebabkan salah satunya oleh bakteri Enterococcus faecalis. Daun Rasamala (Altingia excelsa nornha) dipercaya sebagai antikanker dan antibakteri. Penelitian ini bertujuan untuk mengidentifikasi senyawa dari daun Rasamala yang mempunyai aktivitas sebagai antibakteri Enterococcus faecalis. Penelitian dilakukan dengan cara eksperimental laboratorik menggunakan bakteri Enterococcus faecalis. Ekstrak etil asetat dipisahkan senyawanya dengan berbagai teknik kromatografi yang dipandu dengan uji antibakteri. Hasil penelitian menunjukkan satu senyawa, yaitu apigenin. Senyawa apigenin diuji aktivitas antibakteri terhadap bakteri Enterococcus faecalis dan menunjukkan nilai MIC 15,63 $\mu \mathrm{g} / \mathrm{mL}$. Analisis data menggunakan uji ANACOVA dengan tingkat kemaknaan $\alpha=0,05$. Kesimpulan dari penelitian ini adalah senyawa dari daun Rasamala, yaitu Apigenin memiliki aktivitas sebagai antibakteri Enterococcus faecalis.
\end{abstract}

Kata Kunci: Altingia excelsa; Antibakteri; Apigenin; Enterococcus faecalis

\begin{abstract}
Pulp and periapical disease in children is one of the most common diseases in dental and oral diseases. Enterococcus faecalis is one of the bacteria that causes this disease. Rasamala (Altingia excelsa nornha) leaves are believed to be anticancer and antibacterial. This research aimed to identify the compound of Rasamala leaves that have antibacterial activity against Enterococcus faecalis. The method of this research was a true experimental laboratory design using Enterococcus faecalis bacteria. The ethyl acetate extract was separated its compound by various chromatographic techniques. The research was revealed one compound, which was Apigenin. Apigenin compound were was tested on their the antibacterial activity against Enterococcus faecalis and showed MIC values of 15,63 $\mu \mathrm{g} / \mathrm{mL}$. The data were analyzed by ANACOVA assay with the level of significance $\alpha=0.05$. This research was concluded that the compound from Rasamala leaves, Apigenin, has a strong antibacterial activity in Enterococcus faecalis bacteria.
\end{abstract}

Keywords: Altingia excelsa; Antibacterial; Apigenin; Enterococcus faecalis

\section{PENDAHULUAN}

Karies gigi masih merupakan penyakit gigi dan mulut yang paling umum dijumpai pada anak-anak di Indonesia. Menurut WHO global oral health, indeks karies gigi global diantara anak usia 12 tahun adalah 1,6 gigi yang berarti rata-rata perorang mengalami kerusakan gigi lebih dari satu gigi. ${ }^{1}$ Hasil Survei Riset Kesehatan Dasar tahun 2013, prevalensi

\footnotetext{
* Corresponding author, e-mail: drg.risyandi@unimus.ac.id
} 
penduduk yang mempunyai masalah gigi mulut adalah $23,4 \%$, dengan prevalensi nasional karies aktif adalah $43,4 \%$. Penderita karies gigi di Indonesia memiliki prevalensi sebesar 50-70\% dengan penderita terbesar adalah golongan balita. ${ }^{2}$

Karies gigi desidui yang tidak dirawat dapat dengan cepat meluas dan menyebabkan terbukanya pulpa. $^{3}$ Pulpa yang terbuka menjadi jalan masuk mikroorganisme yang dapat menyebabkan inflamasi, dan bila berlanjut mengakibatkan pulpa menjadi non vital. Gigi desidui dengan infeksi karies yang mencapai pulpa memerlukan perawatan endodontik. Keadaan klinis gigi yang memiliki lesi periapikal atau infeksi saluran akar biasanya ditemukan rasa sakit pada waktu malam hari, dengan ataupun tanpa rangsangan. Secara klinis, dapat ditemukan abses periapikal atau fistula, mobilitas gigi yang abnormal, sensitif pada perkusi atau tekanan. ${ }^{4}$ Pada saluran akar gigi desidui, dapat ditemukan bakteri aerob, anaerob dan bakteri fakultatif. Salah satu bakteri yang paling banyak ditemukan adalah Enterococcus faecalis.

Gigi yang nekrotik perlu dilakukan perawatan saluran akar. ${ }^{5}$ Perawatan saluran akar atau pulpektomi pada gigi desidui dilakukan dengan cara pengambilan jaringan pulpa, preparasi biomekanis, pemberian bahan dressing antar kunjungan, dan pengisian saluran akar. Pada gigi desidui nekrotik yang terinfeksi, umumnya dilakukan perawatan dalam tiga kali kunjungan. Pada setiap kunjungan diberikan bahan sterilisasi untuk mengurangi gejala infeksi, seperti infeksi periapikal. ${ }^{6}$ Bakteri di dalam saluran akar gigi perlu diketahui, sehingga bahan dressing dapat digunakan untuk mengeliminasi bakteri tersebut. ${ }^{7}$

Penggunaan beberapa antibakteri sebagai sterilisasi saluran akar telah digunakan untuk mengeliminasi pertumbuhan bakteri yang masih ada setelah preparasi biomekanis saluran akar dan hal ini berhubungan dengan penyembuhan periradikular. ${ }^{8}$ Rockle's, Tri
Kresol Formalin (TKF), Cresophane, dan CHKM adalah beberapa antibakteri saluran akar pada gigi anak. Sterilitas saluran akar atau berkurangnya jumlah bakteri dalam saluran akar gigi dapat diperiksa dengan kultur bakteri. ${ }^{9}$ Penggunaan antibiotika yang kurang tepat dan tidak adekuat dapat membuat bakteri patogen menjadi resisten dan munculnya mikroba resisten ini penyebab utama kegagalan perawatan endodontik pada anak. ${ }^{10}$ Resistensi bakteri terhadap antibiotik saat ini semakin meningkat dan menjadi masalah utama dalam mengatasi penyakit infeksi. ${ }^{11-12}$ Oleh karena itu, penelitian untuk mencari agen antibakteri baru perlu dilakukan, salah satunya melalui eksplorasi bahan alam yang berasal dari tanaman obat.

Tanaman obat merupakan salah satu sumber daya alam potensial yang dapat dimanfaatkan secara tradisional. Beberapa tanaman obat mengandung senyawa antibakteri. Senyawa antibakteri diantaranya fenol dan senyawa fenolat, kuinon, flavon, flavonol, tanin, kumarin, terpenoid, alkaloid, lektin, dan polipeptida serta campurannya. ${ }^{13}$ Pada saat ini, perdagangan obat-obatan yang berasal dari tumbuhan di seluruh dunia mencapai nilai US\$ 50 milyar setiap tahunnya. ${ }^{13}$ Hal ini menunjukkan betapa pentingnya pencarian obat-obatan yang berasal dari tumbuhan dalam upaya penanggulangan penyakit terutama penyakit-penyakit yang mematikan salah satunya sebagai antibakteri.

Salah satu famili dalam tumbuhan yang banyak diteliti untuk pengobatan antibakteri adalah Hamamelidaceae. Famili Hamamelidaceae terdiri atas 30 genus dan 140 spesies. Tumbuhan famili Hamamelidaceae tersebar di Eropa, Asia, Amerika, dan Afrika. Beberapa tumbuhan dari famili Hamamelidaceae yang pernah diteliti sebagai antibakteri di antaranya adalah Liquidambar orientalis, Liquidambar styraciflua. ${ }^{14,15}$

Indonesia yang memiliki keanekaragaman hayati terbesar di dunia dengan lebih dari 30 ribu spesies tumbuhan 
memiliki khasiat sebagai obat, menjadikan alasan masyarakat untuk mengobati berbagai penyakit secara tradisional dengan pemanfaatan tanaman obat tersebut, salah satu tumbuhan yang digunakan oleh masyarakat adalah daun Altingia excelsa nornha yang berasal dari genus Altingia yang mempunya famili Hammamelidaceae dan lebih dikenal sebagai Rasamala. ${ }^{16}$ Secara tradisional Altingia bermanfaat sebagai obat penurun panas, penambah vitalitas, anti inflamasi dan obat batuk. ${ }^{16}$ Sedangkan pada masyarakat Jawa Barat, daun Rasamala biasanya digunakan sebagai obat batuk dan obat sakit perut. ${ }^{16}$ Secara ilmiah beberapa penelitian telah dilakukan untuk mendapatkan manfaat rasamala, diantaranya berpotensi sebagai antitkanker, dan antibakteri. ${ }^{16,17}$

Mengacu pada pemanfaatan Rasamala secara tradisional, dan ditunjang oleh hasil penelitian dalam menggali potensi Rasamala, maka bukanlah tidak mungkin bahwa Rasamala dapat berpotensi sebagai antibakteri saluran akar gigi dan kelainan periapikal gigi desidui, sehingga penelitian lebih lanjut dalam menggali potensi Rasamala sebagai upaya pencarian obat-obatan antibakteri sangat penting dilakukan.

\section{MATERIAL DAN METODE Bahan}

Sampel yang digunakan adalah daun Rasamala dari pegunungan Wayang Windu, Pangalengan, Bandung dan dideterminasi di Laboratorium Taksonomi Tumbuhan, Departemen Biologi, Fakultas Matematika dan Ilmu Pengetahuan Alam, Universitas Padjadjaran. Subjek penelitian ini adalah Bakteri Enterococcus faecalis.

\section{Ekstraksi daun Rasamala}

Daun kering Rasamala (2 kg) dimaserasi dengan metanol pada suhu kamar selama 24 jam dan dilakukan penampungan maserat sebanyak tiga kali. Maserat yang diperoleh kemudian dipekatkan dengan rotary evaporator sampai diperoleh maserat pekat metanol
(150 g). Maserat pekat metanol dilarutkan dalam air, kemudian dipartisi dengan nheksana dan dihasilkan ekstrak n-heksan dan air. Ekstrak n-heksan dipisahkan dan dipekatkan dengan rotary evaporator, dihasilkan ekstrak pekat n-heksan (130 g). Lapisan air yang diperoleh kemudian dipartisi dengan etil asetat dihasilkan ekstrak etil asetat dan air. Ekstrak etil asetat dipisahkan dan dipekatkan dengan rotary evaporator, dihasilkan ekstrak pekat etil asetat $(120 \mathrm{~g})$. Masing-masing ekstrak dilakukan uji antibakteri terhadap Bakteri Enterococcus faecalis.

\section{Isolasi Senyawa teraktif}

Ekstrak etil asetat $(120$ g) dipisahkan dengan Kromatografi Cair Vakum (KCV) pada fasa diam silika gel G60 dengan fasa gerak n-heksana-etil asetat -metanol dengan gradien $10 \% \quad(\mathrm{v} / \mathrm{v})$. Setelah digabungkan berdasarkan analisis Kromatografi Lapis Tipis (KLT) diperoleh lima fraksi utama (A-E), dan kemudian dilakukan uji aktivitas antibakteri ke lima fraksi tersebut. Berdasarkan nilai MIC berbagai fraksi hasil uji antiproliferasi tersebut, yang mempunyai potensi sebagai antibakteri adalah Fraksi C. Fraksi C (26 g) dipisahkan lebih lanjut dengan $\mathrm{KCV}$ pada fasa diam silika gel G60 dengan fasa gerak n-heksana-etil asetat-metanol dengan gradien $10 \%(\mathrm{v} / \mathrm{v})$. Setelah digabungkan berdasarkan analisis KLT diperoleh lima fraksi (C1-C5), dan kemudian dilakukan uji aktivitas antibakteri ke lima fraksi tersebut, dan menunjukkan bahwa Fraksi C5 memberikan aktivitas potensi sebagai antibakteri.

Fraksi C5 (6 g) dipisahkan lebih lanjut dengan Kromatografi Kolom (KK) pada fasa diam silika gel (70-230 mesh) dengan fasa gerak n-heksan-etil asetat bergradien 5\% sehingga diperoleh lima fraksi utama C5a-C5e. Pada C5a dihasilkan padatan amorf dan direkristalisasi lebih lanjut dengan campuran n-heksana: metanol (4:1), diperoleh senyawa 1 berbentuk kristal putih ( $8 \mathrm{mg}$ ). 


\section{Penentuan struktur senyawa}

Senyawa hasil isolasi ditetapkan sifat fisiknya meliputi warna dan titik lelehnya. Struktur kimia senyawa ditentukan berdasarkan data-data spektroskopi meliputi Ultraviolet (UV), inframerah (IR), resonansi magnetik inti (NMR), dan perbandingan dengan data spektra yang diperoleh dari literatur.

\section{Uji antibakteri Enterococcus faecalis}

Pengujian aktivitas antibakteri ekstrak maupun isolat terhadap Enterococcus faecalis dilakukan dengan metode dilusi. ${ }^{19}$ Parameter yang digunakan adalah kekeruhan yang terjadi akibat pertumbuhan bakteri uji pada konsentrasi tertentu yang disebabkan oleh aktivitas antibakteri ekstrak dan isolat, dibaca dengan alat ELISA reader pada panjang gelombang $630 \mathrm{~nm}$ (BioRad, Japan).

\section{HASIL}

Untuk mengetahui aktivitas antibakteri ekstrak terhadap bakteri $E$. faecalis dilakukan dengan metode dilusi cair. ${ }^{18}$ Aktivitas antibakteri ekstrak terhadap bakteri E. faecalis, dinyatakan dengan nilai MIC, dengan mengacu pada kriteria tingkat aktivitas antibakteri ekstrak bahan alam dalam pengujian sifat antibakteri seperti yang tercantum dalam tabel $1 .{ }^{19}$

Hasil uji antibakteri ekstrak menunjukan ekstrak etil asetat merupakan ekstrak teraktif (Tabel 1), sehingga ekstrak etil asetat dilanjutkan untuk diisolasi. Dengan dipandu uji antibakteri, terhadap ekstrak etil asetat dilakukan metode pemisahan dan pemurnian hingga diperoleh satu senyawa.

\section{Senyawa 1}

Padatan putih, t.l. $298-301{ }^{\circ} \mathrm{C}$, UV $(\mathrm{MeOH}) \lambda$ maks nm $254(\log \varepsilon$ 3,2) dan 364 $(\log \varepsilon$ 2,8); IR (KBr) vmaks cm-1 3429, 1651, 1437, 1020; 1H-NMR (aseton-d6, $500 \mathrm{MHz}) 6,27(1 \mathrm{H}, \mathrm{d}, \mathrm{J}=2,0 \mathrm{~Hz}, \mathrm{H}-6)$, 6,54 (1H, d, J = 2,0 Hz, H-8), 8, 15 (2H, d, J = 9,1 Hz, H-2'; H-6'), 7,02 (1H, d, J = 9,1
Hz, H-3'; H-5'). 13C-NMR (aseton-d6, 125 MHz) $\delta \mathrm{C}$ (ppm): 165,0 (C-2), 104,0 (C-3), 176,0 (C-4), 163,0 (C-5), 99, 1 (C-6), 157,8 (C-7), 94,5 (C-8), 157,8 (C-9), 108,0 (C10), 123,9 (C-1'), 130,5 (C-2', C-6'), 116,3 (C-3', C-5'), 163,0 (C-4').

\section{Struktur Kimia Senyawa 1}

Senyawa 1 diperoleh berupa padatan putih dengan titik leleh $298-301^{\circ} \mathrm{C}$. Spektrum UV senyawa 1 menunjukkan adanya dua pita serapan pada $\lambda_{\text {maks }} 254$ dan 364 nm. Spektrum IR senyawa 1 menunjukkan adanya gugus -OH yang teramati pada $V_{\text {maks }} 3429 \mathrm{~cm}^{-1}$ dan regang C$\mathrm{O}$ pada $\mathrm{V}_{\text {maks }} 1020 \mathrm{~cm}^{-1}$. Adanya kerangka flavon ini didukung pula oleh spektrum ${ }^{1} \mathrm{H}$ NMR yang menunjukkan adanya dua proton yang terjodoh secara meta pada $\delta \mathrm{H}$ 6,34 $\left({ }^{1} \mathrm{H}, \mathrm{d}, 1,9\right)$ dan pada $\delta \mathrm{H} 6,11\left({ }^{1} \mathrm{H}, \mathrm{d}\right.$, 1,9) pada cincin B. Spektrum ${ }^{13} \mathrm{C}$ NMR menunjukkan adanya 15 sinyal karbon. Berdasarkan data DEPT 135, kelima belas karbon tersebut terdiri atas tujuh metin $\mathrm{sp}^{2}$ yang beresonansi pada daerah $\delta \mathrm{C} 96,1$ 129,4 ppm, enam karbon kuartetner sp2 teroksigenasi yang beresonansi pada medan lemah $\delta \mathrm{C} 159,8$ - 165,9 ppm, serta satu gugus karbonil yang beresonansi pada $\delta \mathrm{C}$ 183,5 ppm. Data NMR senyawa 1 dibandingkan dengan senyawa apigenin dari tanaman desmotachia bipinnata (L), ${ }^{21}$ memiliki kesesuaian yang sangat tinggi, sehingga senyawa 3 diidentifikasi sebagai apigenin (Gambar 1).

Tabel 1. Nilai MIC berbagai ekstrak daun Rasamala.

\begin{tabular}{lc}
\hline Ekstrak & MIC $(\boldsymbol{\mu g} / \mathbf{m L})$ \\
\hline Methanol & 89,41 \\
$n$-heksan & 107,85 \\
etil asetat & 14,45 \\
Air & 108,02 \\
\hline
\end{tabular}<smiles>O=c1cc(-c2ccc(O)cc2)oc2cc(O)cc(O)c12</smiles>

Gambar 1. Struktur apigenin (1) 
Untuk mengetahui aktivitas antibakteri senyawa $\mathbf{1}$ terhadap bakteri $E$. faecalis dan dilakukan juga dengan metode dilusi cair. ${ }^{19}$ Aktivitas antibakteri senyawa 1 terhadap bakteri E. faecalis, dinyatakan dengan nilai MIC, dengan mengacu pada kriteria tingkat aktivitas antibakteri senyawa bahan alam dalam pengujian sifat antibakteri, yang menghasilkan MIC sebesar $15,63 \mu \mathrm{g} / \mathrm{mL} .^{20}$

\section{PEMBAHASAN}

Apigenin (4',5,7-trihydroxyflavone), adalah anggota dari flavon dan masuk dalam subklas flavonoids. Trihydroxyflavone atau Apigenin adalah suatu zat alami yang terdapat dalam bioflavonoid yang banyak ditemukan pada buah dan sayur. Apigenin memiliki toksisitas lebih rendah bila dibandingkan dengan flavonoids lain. ${ }^{21}$ Apigenin memiliki sejumlah fungsi biologis diantaranya sebagai anti-mutagenic, antiinflammatory, anticarcinogenic, anti-viral, dan free-radical scavenging properties. Apigenin memiliki potensi untuk menghambat pertumbuhan bakteri gram positif dan negatif seperti E. coli, S. Aureus, Bacillus Aureus, dan pseudomonas aeruginosa. Senyawa kimia apigenin diduga dapat menghambat pertumbuhan bakteri gram positif sama baiknya dengan gram negatif. Efek antibakteri dari apigenin yang dikombinasikan dengan ampisilin atau gentamisin menunjukkan efek bakterisidal yang kuat terhadap bakteri patogen dalam rongga mulut. ${ }^{19}$

Apigenin mempunyai aktivitas antibakteri lebih signifikan pada $S$. Thyphimurium dan P. Mirabilis. Aktivitas antibakteri ini dimungkinkan karena kandungan kimia alami dari apigenin dan juga permeabilitas membran sel. ${ }^{21}$

\section{KESIMPULAN}

Kesimpulan dari penelitian ini adalah senyawa apigenin yang berhasil disolasi dari daun rasamala mempunyai aktivitas menghambat pertumbuhan bakteri Enterococcus faecalis.

\section{DAFTAR PUSTAKA}

1. Erik, P. Continuous improvement of oral health in the 21st century - the approach of the WHO Global Oral Health Programme. Geneva: WHO. 2013.

2. Soendoro dkk. Riset Kesehatan Dasar; RISKESDAS. Jakarta: Balitbang Kemenkes RI. 2013.

3. Love, Robert \& Jenkinson, H.F.. Invasion of Dentinal Tubules by Oral Bacteria. Critical reviews in oral biology and medicine : an official publication of the American Association of Oral Biologists. 2002; 13(2) :171-183.

4. Jeffrey, A.D. Mc Donald and Avery: Dentistry for the child and adolence. Elsevier. 2012.

5. Grossman, L.L., Oliet, S., dan Rio, C. E. D. Ilmu endodontik dalam praktek (Terj). Jakarta: EGC. 1995.

6. Bastawi, A.E. Pulp treatment, dalam Handbook of Clinical Pedodontics, Kenneth D. Snawder, 177-178, The C.V. Mosby Company, Missouri. 1980.

7. Silva, L.A.B., Nelson-Filho, P., Faria, G., Souza-Gugelmin, M.C.M., and Ito, I.Y. Bacterial Profile in Primary Teeth with Necrotic Pulp and Periapical Lesions. Braz Dent J. 2006; 17(2): 144-148.

8. Sjogren,U., Figdor,D., Spangberg,L., and Sundqvist, G., The Antimicrobial Effect of Calcium Hydroxide as a Short-term Intracanal Dressing. Int Endod J. 1991; 24: 119-125.

9. Sathorn,C., Parashos,P., and Messer, H., Antibacterial Efficacy of Calcium Hydroxide Intracanal Dressing : A Systematic Review and Meta-analysis. Int Endod J. 2007; 40: 2-10.

10. Refdanita, dkk. Pola Kepekaan Kuman Terhadap Antibiotika Di Ruang Rawat Intensif Rumah Sakit Fatmawati Jakarta Tahun 2001 - 2002. Makara, J Kesehatan. 2004; 8(02) : 41-48.

11. R.O Elsayed, N.H Bakr and Y.E Ibrahim. Quality of root canal 
treatment performed by undergraduate dental student at the university of khourtoum sudan. Australian Endodontic Journal. 2011; 37(2):5660.

12. Pazelli,L.C., Freitas,A.C., Ito,I.Y., Souza-Gugelmin,M.C.M., Medeiros,A.S., dan Nelson-Filho,P. Prevalence of microorganisms in root canals of human deciduous teeth with necrotic pulp and chronic periapical lesions. Pesqui Odontol Bras. 2003; 17(4): 367-371.

13. G.M. Cragg and D.J Newman. Plant product as antimicrobial agent. Clin microbiol. Rev. 2005; 12(4): 564-582.

14. G. Okmen, Z. Cantekin, M.I. Alam, O. Turkcan, and Y. Ergun. Antibacterial and Antioxidant Activities of Liquidambar Orientalis Mill. Various Extracts Against Bacterial Pathogens Causing Mastitis. Turkish Journal of Agriculture - Food Science and Technology. 2017; 5(8): 883-887.

15. G. F. F. Mancarz, A. C. P. Lobo, M. B. Baril, F. A. Franco, and T. Nakashima. Antimicrobial and Antioxidant Activity of the Leaves, Bark and Stems of Liquidambar styraciflua L. (Altingiaceae). Int.J. Curr. Microbiol. App. Sci. 2016; 5(1), 306-317.

16. Anwar, R. Bioactive compound from Rasamala (Altingia excels noronha) leaves as c-myc protoncogene expression supressor of human tongue cancer cell. Dentino. 2018; III(2).

17. Pangestika, A.R.. Aktivitas antibakteri minyak atsiri daun rasamala (Altingia excelsa Nornha ). Bogor. Institut Pertanian Bogor. Skripsi. 2017.

18. Wardhana, D.F., Rukmo, M., dan Budi, A.T. Daya Antibakteri kombinasi metronidazol, siprofloksasin dan minosiklin terhadap enterococcus faecalis. Jurnal Ilmu Konservasi Gigi Unair 2008; 1(1) : 2328.

19. M. M. Rahman, A. I. Gray, P. Khondkar, and S. D. Sarker. Antibacterial and Antifungal Activities of the Constituents of Flemingia paniculata. Pharmaceutical Biology, 2008; 46(5), 356-359.

20. S. Ramya, P.J. Jepachanderamohan, N. Alaguchamy, M. Kalayanasundaram, and R. Jayakumararaj. In Vitro Antibacterial Prospective of Crude Leaf Extracts of Melia azedarach Linn. against Selected Bacterial Strains. Ethnobotanical Leaflets. 2009; 13(2): 54-58.

21. E.R. Saad, M.A. Radwan, S.A.E. Mohamed, and S.M. Sherby. Antibacterial screening of some essential oils, monoterpenoids and novel $\mathrm{N}$-methyl carbamates based on monoterpenoids against Agrobacterium tumefaciens and Erwinia carotovora. Archives of Phytopathology And Plant Protection. 2008; 41(6): 451-461. 